Article (refereed)

Stokes, Victoria J.; Morecroft, Michael D.; Morison, James I.L.. 2010 Comparison of leaf water use efficiency of oak and sycamore in the canopy over two growing seasons. Trees - Structure and Function, 24 (2). 297-306. 10.1007/s00468-009-0399-8

(C) Crown copyright 2009

This version available http://nora.nerc.ac.uk/9604/

NERC has developed NORA to enable users to access research outputs wholly or partially funded by NERC. Copyright and other rights for material on this site are retained by the authors and/or other rights owners. Users should read the terms and conditions of use of this material at http://nora.nerc.ac.uk/policies.html\#access

This document is the author's final manuscript version of the journal article, incorporating any revisions agreed during the peer review process. Some differences between this and the publisher's version remain. You are advised to consult the publisher's version if you wish to cite from this article.

www.springerlink.com 


\section{Comparison of leaf water use efficiency of oak and sycamore in the canopy over two growing seasons}

Victoria J. Stokes ${ }^{1 \star}$, Michael D. Morecrofe and James I. L. Morison ${ }^{1}$

${ }^{1}$ Department of Biological Sciences, University of Essex, Colchester, UK.

Now working for Forest Research, Farnham, UK.

${ }^{2}$ Centre for Ecology and Hydrology, Wallingford, UK.

Now working for Natural England, Cheltenham, UK.

* Corresponding author.

Full mailing addresses:

1) Dr. V. J. Stokes, Forest Research, Alice Holt Lodge, Wrecclesham, Farnham, Surrey, GU10 4LH, UK. victoria.stokes@forestry.gsi.gov.uk

Tel: 01420526156

Fax: 01420520558

2) Dr. M. D. Morecroft, Natural England,

Evidence Team, John Dower House, Crescent Place, Cheltenham, GL50 3RA, UK. michael.morecroft@naturalengland.org.uk

Tel: 03000600006

1) Dr. J. I. L. Morison,

Forest Research, Alice Holt Lodge, Wrecclesham, Farnham, Surrey, GUl 0 4LH, UK. james.morison@forestrv.gsi.gov.uk Tel: 01420526175

Suggested keywords: Acer, Carbon isotope discrimination, $J^{13} C$, Quercus, stomatal conductance, sun and shade.

1 table, 5 figures

Suggested running title: water use efficiency of oak and sycamore 


\section{Summary}

The seasonal trends in water use efficiency of sun and shade leaves of mature oak (Quercus robur) and sycamore (Acer pseudoplatanus) trees were assessed in the upper canopy of an English woodland. Intrinsic water use efficiency (net $\mathrm{CO}_{2}$ assimilation rate/leaf conductance, $\mathrm{A} / \mathrm{g}$ ) was measured by gas exchange and inferred from $\mathrm{C}$ isotope discrimination $\left(8^{13} \mathrm{C}\right)$ methods. Shade leaves had consistently lower $8{ }^{13} \mathrm{C}$ than sun leaves (by l-2\%o), the difference being larger in sycamore. Buds had distinct sun and shade isotopic signatures before bud break, and received an influx of ${ }^{13} \mathrm{C}$-rich $\mathrm{C}$ before becoming net autotrophs. After leaf full expansion, $8{ }^{13} \mathrm{C}$ declined by $1-2 \%$ o gradually through the season, emphasising the importance of imported carbon in the interpretation of leaf $8{ }^{13} \mathrm{C}$ values in perennial species. There was no significant difference between the two species in the value of intrinsic water use efficiency for either sun or shade leaves. For sun leaves, season-long $\mathrm{A} / \mathrm{g}$ calculated from $8{ }^{13} \mathrm{C}\left(72-78 \mathrm{Jlmol} \mathrm{CO} \mathrm{CO}_{2}\left[\mathrm{~mol} \mathrm{H}_{2} \mathrm{Or}^{1}\right)\right.$ was $10-16 \%$ higher than that obtained from gas exchange and in situ estimates of leaf boundary layer conductance. For shade leaves, the gas exchange derived values were low, only $10-18 \%$ of the $8^{13} \mathrm{C}$-derived values. This is ascribed to difficulties in obtaining a comprehensive sample of gas exchange measurements in the rapidly changing light environment. 


\section{Introduction}

Terrestrial plants have evolved complex stomatal regulation mechanisms to avoid dehyd ration while allowing $\mathrm{CO}_{2}$ uptake. The ratio of net $\mathrm{CO}_{2}$ assimilation rate (A) per unit transpiration rate (1) is widely regarded as an important determinant of plant growth and success (see Morison et al. 2008). The ratio AfT is often termed water use efficiency (WUE), or transpiration efficiency. There are several key determinants ofWUE. Firstly, air humidity and leaftemperature affect the ratio as they determine the 'driver' for transpiration, the leaf-to-air vapour pressure difference ( e). Thus several researchers have instead used the ratio of net $\mathrm{CO}_{2}$ assimilation rate to stomatal conductance to water vapour (A/g $\mathrm{g}_{5}$ because $T=e \cdot g e \cdot g{ }_{5}$ if the leaf is well-coupled to the air stream (i.e. when leaf conductance, $g$, is principally determined by $\mathbf{g}_{5}$ ). This is often referred to as 'intrinsic water use efficiency' (Osmond et al. 1980; Seibt et al. 2008). While the $A \lg _{5}$ ratio is conservative, because of the close correlation of $A$ and $g_{5}$ that normally occurs in changing conditions (e.g. Jones 2004), it is not a constant, as $g_{5}$ may vary with $\boldsymbol{e}$ or other factors in order to conserve leaf water status. At any given ambient C02 concentration ( $\mathrm{Ca}$, llmol mor ${ }^{1}$ ), the ratio Algs is linearly related to the intercellular C02 partial pressure (C., f.tmol mor ${ }^{1}$ ) which reflects the balance between assimilation rate and stomatal aperture; high $\mathrm{Ci}$ indicates low WUE (see e.g. Jones 2004; Morison et al. 2008).

Secondly, the leaf physiological state, especially the nitrogen status and the partitioning between light harvesting and carboxylation components, affects the rate of photosynthesis (Evans 1989). Comparison across broad plant types has shown that a high leaf $\mathrm{N}$ content can confer a high WUE (Field 1983; Gutschick 1999). Nitrogen is usually distributed in the canopy in such a way as to maximise photosynthesis, corresponding with the distribution of mean light intensity (e.g. Ellsworth and Reich 1993; Kull and Niinemets 1993; Hirose 2005). Across habitats and plant functional types and in different growth conditions stomatal conductance is usually tightly correlated with photosynthetic rate (e.g. Wong et al. 1979; Schulze et al. 1994). Thus it might be expected that leaves in shaded positions in canopies should have similar Algs to sun leaves, potentially resulting in higher WUE in the shade, because of lower leaf temperatures and higher humidity, but there is surprisingly little published data. However, in previous work in an English oak woodland, Morecroft and Roberts (1999) found that shade leaves in the upper canopy often had rates of $\mathrm{CO}_{2}$ assimilation near zero, although $\mathrm{g}_{5}$ was appreciable. Therefore, C. was usually higher and measured WUE lower in the shade. Leaves in the shade may depend on C02 uptake during brief sunflecks (Pearcy et al. 1996; Pearcy 1998), and thus maintain open stomata to utilise these episodes, resulting in low average WUE. However, the contribution of shade leaves to the overall water and carbon balance of the canopy is unclear.

Measurement of leaf gas exchange in tree canopies is laborious. It is difficult to obtain a reliable sample because of access difficulties, the continually changing conditions, and the very different response times of $A$ and $\mathbf{g}_{5}$ to light. This is a particular problem for shaded leaves where light intensity changes rapidly with leaf movement. Thus a gas exchange sample may well be inadequate and biased, especially given that leaf chambers can influence the conditions around the leaf, particularly $\boldsymbol{e}$. Better estimates of long-term water use efficiency could potentially be provided by the ${ }^{13} \mathrm{C}$ discrimination method (Farquhar et al. 1982). Biochemical discrimination against the heavier isotope ${ }^{13} \mathrm{C}$, compared to ${ }^{12} \mathrm{C}$, results in the incorporation of higher levels of ${ }^{13} \mathrm{C}$ into leaf tissues when $\mathrm{C} / \mathrm{Ca}$ is low, as occurs in sun leaves. Farquhar et al. $(1982,1989)$ 
showed that season long, leaf-scale WUE, integrated up to the sample collection date can be calculated from the ${ }^{13} \mathrm{C}$ discrimination data:

$$
A^{*} I T^{*}=\mathrm{Ca}[1-(\mathrm{C} / \mathrm{Ca})] /(1.6 f l e)
$$

where the factor 1.6 is the ratio of the diffusivities of $\mathrm{CO}_{2}$ and water vapour in air. It follows that an integrated "intrinsic water use efficiency" $\left(\mathrm{A}^{*} / \mathrm{g} *\right)$ can also be calculated:

$$
A^{*} l g^{*}=\mathrm{Ca}[1-(\mathrm{C} / \mathrm{Ca})] / 1.6
$$

However, WUE derived from carbon isotope discrimination cannot easily be scaled up to a whole plant or canopy level, as not all carbon and water losses are accounted for by leaf $A$ or $T$ (Farquhar et al. 1989). Carbon may be exported from the shoots or water may be lost independent of $\mathrm{CO}_{2}$ uptake (for example, through incompletely closed stomata at night). In addition, reductions in gs cause changes in leaf temperature, affecting fle, although the size of the temperature change depends upon the degree of coupling of the leaf to the air stream. Most importantly, the $8{ }^{13} \mathrm{C}$ of leaf material changes during leaf growth in woody species because of changing carbon sources from stored reserves to current photosynthate (e.g. Lowdon and Dyck 1974; Damesin and Lelarge 2003; Helle and Schleser 2004). Thus a general decline in $8^{13} \mathrm{C}$ has been observed as leaves mature (Garten and Taylor 1992; Rao et al. 1994; Terwilliger 1997; Morecroft and Roberts 1999; Chevillat et al. 2005) and stems and buds often have higher $8{ }^{13} \mathrm{C}$ (less negative) than leaf tissues (e.g. Helle and Schleser 2004). Furthermore, use of stem reserves and timing of cambial activity for radial growth in the spring differs between ring-porous and diffuse-porous species (Kozlowski 1992; Barbaroux and Breda 2002; Helle and Schleser 2004) and may also differ for leaf growth.

Acer and Quercus species co-occur in many temperate deciduous woodland habitats, but Acer spp. have often been shown to be more drought sensitive than Quercus spp. (e.g. Oren and Pataki 2001; Bovard et al. 2005). They also show different patterns of seasonal leaf and photosynthetic development (e.g. Wilson et al. 2000). Therefore, we expected differences in WUE between species and between sun and shade leaves. In this study, both gas exchange measurements and $8{ }^{13} \mathrm{C}$ determination were used to determine the season-long, integrated WUE of oak (Q. robur (L.)) and sycamore (A. pseudoplatanus (L.)) sun and shade leaves in the upper part of a mature canopy. The aims were to:

1) compare values of intrinsic water use efficiency, Algs, for both sun and shade leaves in the upper canopy of the two contrasting tree species;

2) to describe the seasonal pattern of leaf $8{ }^{13} \mathrm{C}$ in the canopy in the ring-porous, determinate oak with the diffuse-porous, indeterminate sycamore;

\section{Methods and Materials}

Fieldwork was carried out at Wytham Woods, Oxfordshire, UK $\left(51^{\circ} 46^{\prime} \mathrm{N} 1^{\circ} 20^{\prime} \mathrm{W}\right.$, Grid reference SP4608), a W8e woodland in the British National Vegetation Classification (Rodwell 1991); Geranium robertianum sub-community of Fraxinus - Acer campestre - Mercurialis (W8). The dominant canopy species was pedunculate oak (Q. robur) with sycamore (A. pseudoplatanus), ash, (Fraxinus excelsior L.), beech, (Fagus sylvatica L.) and birch, (Betula pendula Roth.) also reaching the upper canopy. Maximum canopy height was $17.5 \mathrm{~m}$, and canopy depth was approximately $10 \mathrm{~m}$; a scaffolding and plank walkway allowed access to the upper canopy. Oak trees were 150-200 years old and sycamore trees were 50-100 years old. Further site 
details are given by Morecroft et al. (1998, 2003), Morecroft and Roberts (1999) and Stokes et al. (2006).

Leaves were sampled from the upper 3m ofthe crowns of5 oak and 5 sycamore trees, at weekly (during Spring and Autumn) or fortnightly (during Summer) intervals for two growing seasons. The 'sun' leaves were from very exposed canopy locations and were rarely shaded and shade leaves were from sheltered upper-canopy locations that rarely received direct sun due to shading by other leaves.

\section{Carbon isotope discrimination and $N$ content determination}

In 1999 carbon isotope discrimination was determined on pooled samples of the same species and light environment for each date. In 2000 each leaf sample was analysed individually, allowing intraspecific differences to be analysed; however, for the early Spring bud samples, tissues were pooled as in 1999, because the mass of individual buds was too low. Oven dried leaf samples were ground using a liquid nitrogen freezer/mill (SPEX 6700, Glen Creston Ltd, Stanmore, Middlesex, UK). Samples were weighed ( $2 \mathrm{mg} \pm 0.2 \mathrm{mg}$ in 1999, $1.1 \mathrm{mg} \pm 0.02 \mathrm{mg}$ in 2000) into a $6 \times 4 \mathrm{~mm}$ tin capsule using a high-precision microbalance. The sealed capsules were combusted using an automated Carlo Erba NA 1500 (VWR International Ltd, Poole, Dorset, UK) elemental analyser coupled to an isotope ratio mass-spectrometer. Reference samples were analysed regularly for quality control. The nitrogen content of the ground leaf samples was also analysed by a mass spectrometer (Eiementar Vario EL, Elementar Analysensysteme GmbH, Hanau, Germany).

\section{Gas exchange analysis}

Measurements of assimilation rate $\left(A\right.$, )lido! $\mathrm{CO}_{2} \mathrm{~m}^{2}{ }^{2} \mathrm{~s} \cdot \backslash$ transpiration rate $\left(T\right.$, mmol $\mathrm{H}_{2} \mathrm{O}$ vapour $\mathrm{m}^{-2} \mathrm{~s} \cdot{ }^{3}$ ) and stomatal conductance to water vapour (gs, mmol m. ${ }^{2} \mathrm{~s}^{1}$ ) were made on oak and sycamore sun and shade leaves under ambient light conditions throughout the season from May to November in 1999 and 2000. Measurements were made using a portable gas exchange system (CIRAS 1 \& 2, PP Systems, Hitchin, Herts, UK) fitted with a $2.5 \mathrm{~cm}^{2}$ broadleaf leaf cuvette (PLC (B) and PLC6U, PP Systems). The cuvette $\mathrm{CO}_{2}$ concentration and humidity were set to ambient levels. Leaf temperature was calculated from energy balance calculations, and boundary layer conductance was measured as 3.6 and $2.8 \mathrm{~mol} \mathrm{~m}{ }^{2} \mathrm{~s}^{1}$ for the two different cuvettes. Measurements were taken between 09:00h and 14:00h GMT several times a week in dry weather conditions. On each occasion, for each tree and light environment five leaves were measured. Five recordings were taken over a period of one minute for each leaf, which were then averaged. Means and standard errors were calculated using the five leaf means per tree for each occasion and for sun and shade conditions separately. Intrinsic water use efficiency was calculated as the ratio of Algs from the mean $A$ and gs values for each tree, light environment and time.

\section{Statistical Analysis}

Repeated measures Analysis of Variance was used with 'date' as the within-subject factor and year, species or light environment as between-subject factors, as appropriate. Analyses were carried out with the GLM function in SPSS v11.5.

\section{Results}




\section{Gas exchange measurements of leaf A and Algs}

Mean daily values of net $\mathrm{C}_{2}$ assimilation rate, $A$, showed strong seasonal patterns in the sun leaves that differed between the two species (Fig. 1). For oak sun leaves, $A$ increased over the first 50 days after bud break (DOY (day of year) 105), was high (up to 17 ) $11110 \mathrm{~m}^{-2} \mathrm{~s}^{-1}$ ) but variable in the mid-season, before declining after DOY 270. In contrast, sycamore sun leaf $A$ was moderate (approximately 10 ) $11110 \mathrm{~m} \mathrm{~m}^{2} \mathrm{~s}^{-}$) early in the year (from first measurements up to DOY 225), then declined to low values by DOY 280. Shade leaf assimilation rate was often below zero in both species (indicating net respiration). Mean seasonal values of $A$ in sycamore sun leaves were $63 \%$ and $69 \%$ of the rates in oak leaves, in 1999 and 2000 respectively (Table 1), but there was no significant difference in $A$ of shade leaves between species.

Intrinsic water use efficiency, $A l g_{5}$, showed similar seasonal patterns to $A$ (Fig. 2), with the low and sometimes negative $A$ rates of shade leaves resulting in low or negative $A g_{5}$. The considerable variation in $A / g_{5}$ indicated that there was little correlation of $g_{5}$ with $A$ across the different measurement conditions, although mean seasonal values were closely similar between species (Table 1).

\section{${ }^{13} \mathrm{C}$ discrimination in leaves}

There were significant differences in whole leaf $8{ }^{13} \mathrm{C}$ between sun and shade leaves in both years ( $\mathrm{P}<0.001$, Fig. 3 and Table 1 ) but not between species. In early and mid-season, shade leaves had approximately $1.5-2 \%$ o lower $8{ }^{13} \mathrm{C}$ values than sun leaves in sycamore, and $1 \%$ o lower in oak (Fig. $3)$. However, in both years, sun and shade values converged slightly by the end of the season, after the onset of senescence (approximately DOY 280). The $8^{13} \mathrm{C}$ values of leaves of each species and light environment did not vary significantly between years. In the mid-season period between DOY 180-275 in both years sycamore sun leaves had slightly higher $8{ }^{13} \mathrm{C}$ than the corresponding oak sun leaves (Figs 3 and 4). In 2000 samples for different trees were not pooled, and there were significant differences between trees $(\mathrm{P}<0.001)$. Mean $8{ }^{13} \mathrm{C}$ over the season for sun leaves of different trees ranged from -26.8 (S.E. \pm 0.2$)$ to $-28.2( \pm 0.3)$ in oak and $-26.7( \pm 0.4)$ to $-28.0( \pm 0.3)$ in sycamore. The tree-to-tree variation in $8{ }^{13} \mathrm{C}$ was the same size as the mean difference between sun and shade leaves.

In early 2000 (DOY 102) the bud $8{ }^{13} \mathrm{C}$ values were $3-5 \%$ o higher than in the leaves at the end of the previous season (Fig. $3 \mathrm{~b}$ and Fig. 4). Furthern10re, the $8{ }^{13} \mathrm{C}$ of the buds were distinct, ranging from $-23.5 \%$ o for sycamore sun buds, to $-28.2 \%$ o for oak shade buds, although the small size of the buds meant that samples had to be pooled, so no statistical comparison can be done. As buds swelled the $8^{13} \mathrm{C}$ values increased sharply, then declined as buds broke (bud break was defined as $50 \%$ of buds showing green tissues). From DOY 135 (leaves approximately half expanded) leaf $\mathrm{CO}_{2}$ assimilation increased, particularly in sycamore, corresponding with the markedly more rapid decline in $8{ }^{13} \mathrm{C}$ of sycamore leaves than oak leaves. From DOY 120 to 170 all leaf types became more depleted in $8{ }^{13} \mathrm{C}$ by $2-4 \%$ o, corresponding with rapid leaf expansion up to DOY 140. Figure 4 demonstrates the high $8^{13} \mathrm{C}$ in buds compared to leaves at the end of the year, the reduction in $8{ }^{13} \mathrm{C}$ as leaves mature and the similarity in $8{ }^{13} \mathrm{C}$ values between the two years.

Changes in leaf $8{ }^{13} \mathrm{C}$ were associated with changes in tissue composition as the leaves matured, as indicated by the leaf\% water content (Fig. 5). There was an almost linear reduction for most 
of the growing season, although the first four $8{ }^{13} \mathrm{C}$ values in the time sequence were considerably higher for sycamore. These linear relationships were approximately parallel for both sun and shade positions and species (Fig. 5) and were also similar between years (data not shown). It is clear that the whole leaf $8{ }^{13} \mathrm{C}$ values were different between sun and shade leaves, but early in the season were strongly influenced by the signal of imported carbohydrate. It is only after leaves reached maturity that the $8{ }^{13} \mathrm{C}$ values stabilised to those reflecting the leaf activity.

\section{Calculated $A^{*} \lg *$}

Long term intrinsic water use efficiency $\left(A^{*} / g^{*}\right)$ was calculated from the $8{ }^{13} \mathrm{C}$ values after budbreak according to Farquhar et al. (1982) assuming an ambient canopy $\mathrm{CO}_{2}$ concentration of $350 \mathrm{~J} . L m o l$ mor ${ }^{1}$ (Table 1). For sun leaves in both oak and sycamore the $8^{13} \mathrm{C}$-derived $A^{*} / g^{*}$ value was approximately 50\% higher than Algs derived from gas exchange measurements throughout the season. However, valid comparison should use $g$ not $\mathbf{g}_{5}$, and therefore gb must be known, unless $\mathrm{gb}>>\mathrm{g}_{5}$. Furthermore, gb needs to be the value in the canopy, not the value in the leaf chamber during gas exchange measurement. In $2001 \mathrm{gb}$ was estimated through most of the leafed season using heated leaf replicas (see Stokes et al. 2006). Mean values of gb (for water vapour) were 0.53 and $0.48 \mathrm{~mol} \mathrm{~m}-^{2} \mathrm{~s}^{-}{ }^{1}$ for oak sun and shade, respectively, and $0.35 \mathrm{~mol} \mathrm{~m}^{-}{ }^{2} \mathrm{~s}^{1}$ for both sycamore leaf positions. Assuming these mean gb values were also representative of those in 1999 and 2000, they were used to calculate mean seasonal Alg from the daily mean gas exchange values (Table 1). For oak and sycamore sun leaves the estimated mean Alg values were only $18 \%$ and $13 \%$ lower than the $8{ }^{13} \mathrm{C}$-derived $A^{*} l g^{*}$ in 2000 (Table 1). For shade leaves the $8{ }^{13} \mathrm{C}$-derived $A * / g *$ values were $15-25 \%$ lower than the value for sun leaves. However, $A * l g *$ was 5 to 6 -fold higher than the very low value of $A / g$ estimated from gas exchange and gb measurements (Table 1).

\section{Discussion}

Assimilation rate and intrinsic water use efficiency values

Values of net $\mathrm{CO}_{2}$ assimilation rate for fully-exposed sun leaves (Table 1) were similar to those found in other studies with deciduous oak (Quercus spp.) and maple (Acer spp.) trees (e.g. Sullivan et al. 1996; Bassow and Bazzaz 1998). The differences between $A$ of sun and shade leaves found here do not agree as closely with those previously published, probably because the degree of shade is difficult to compare. Catovsky et al. (2002) reported mean $A$ in the sun and shade of 13 and 2 J.Lmol m- ${ }^{2}$ s- $^{1}$, respectively, for Q. rubra and 6 and $2 \mathrm{JJLmol} \mathrm{m}-^{2} \mathrm{~s}^{-}{ }^{1}$ for A. rubrum, the higher rates in the shade than observed here suggesting less dense shade (see Table 1).

Intrinsic water use efficiency, Algs of sun leaves (approx. $50 \mathrm{~J} . \mathrm{Lmol} \mathrm{CO}_{2}\left[\mathrm{~mol} \mathrm{H}_{2} \mathrm{Or}^{1}\right.$ ) was similar to other studies (e.g., 35 to 50 J.Lmol $\mathrm{CO}_{2}$ [mol $\mathrm{H}_{2} \mathrm{Or}^{1}$ in Q. crispula (Matsumoto et al. 2005; Muraoka and Koizumi 2005). For A. pseudoplatanus, Holscher (2004) reported upper canopy values of Algs of 64-100 J.Lmol $\mathrm{CO}_{2}$ [mol $\mathrm{H}_{2} \mathrm{Of}^{1}$. The results of Catovsky et al. (2002) for $A$. rubrum and Q. rubra indicate mean Algs $=75$ and 51 J.Lmol $\mathrm{CO}_{2}\left[\mathrm{~mol} \mathrm{H}_{2} \mathrm{Or}^{1}\right.$, respectively, in the upper canopy layer. However, values for shade leaves measured here (4-9 J.Lmol $\mathrm{CO}_{2}\left[\mathrm{~mol} \mathrm{H}_{2} \mathrm{Or}\right.$ ${ }^{1}$ )were much lower than the 20 and $11 \mathrm{J.Lmol} \mathrm{CO}_{2}$ [mol $\mathrm{H}_{2} \mathrm{Of}{ }^{1}$ thatCatovsky et al. observed in the lower canopy. The shade leaves in these canopies may be responding similarly to some forest floor species, by maintaining moderate gs maximising $\mathrm{CO}_{2}$ assimilation when they are briefly illuminated (e.g. Pearcy et al. 1996). Urban et al. (2007) found that shade leaves of $A$. 
pseudoplatanus reached $90 \%$ of photosynthetic induction and stomatal opening more quickly than sun leaves.

\section{Comparison of $8^{3} \mathrm{C}$ values between species}

The values of $0{ }^{13} \mathrm{C}$ for leaves of both species measured here $(-27 \%$ o to $-29 \%$ o, Table 1$)$ were closely comparable to others for broadleaved, temperate, humid forests (see Table compiled by Chevillat et al. 2005, and Holscher 2004). There was no significant difference in $8{ }^{13} \mathrm{C}$ between the two species agreeing with the similarity in gas-exchange derived Algs (Table 1 and Fig. 2). Little difference between leaf $8{ }^{13} \mathrm{C}$ values of co-occurring species has also been found by Garten and Taylor (1992), Holscher (2004) and Chevillat et al. (2005). This agrees with the generally conservative value of $\mathrm{C} / \mathrm{Ca}$ that is found in similar plant functional types and habitats, due to the close match of stomatal conductance and $\mathrm{CO}_{2}$ assimilation rate (e.g. Wong et al. 1979; Schulze et al. 1994). In contrast, differences between species in $0^{13} \mathrm{C}$ have been found that accord with the species preferred ecological conditions, for example in comparison of mature trees of $Q$. robur and Q. petraea, which differ by just $1 \% 0$ (Ponton et al. 2001).

\section{Sun and shade leaves}

The $1 \%$ o to $2 \%$ o lower $8{ }^{13} \mathrm{C}$ values in shade than sun leaves were similar to many previous observations (e.g. Buchmann et al. 1997; Pearcy 1998; Morecroft and Roberts 1999; LeRoux et al. 2001; Helle and Schleser 2004; Chevillat et al. 2005). Hypotheses previously suggested include increased water stress in sun leaves and thus increased stomatal limitation and consequent reduced $\mathrm{C} / \mathrm{Ca}$, differences in ambient air $8{ }^{13} \mathrm{C}$ due to distance from respiratory sources in the soil, and differences in Lle or differences in light and consequently altered internal conductance to $\mathrm{CO}_{2}$ (Le Roux et al. 2001; Seibt et al. 2008). However, here as the sun and shade leaves sampled were close to each other in the upper canopy, and as these leaves were usually well-coupled to the canopy air flow (Stokes et al. 2006) we agree with Chevillat et al. (2005) and others that differences in source air are unlikely. It is probable that it is caused by the higher light regime, driving higher $\mathrm{CO}_{2}$ assimilation rates, and consequently a lower $\mathrm{C} / \mathrm{Ca}$ than in shade leaves. The difference in $8{ }^{13} \mathrm{C}$ between sun and shade leaves may be larger in sycamore leaves $(-1.5 \%$ o to $2.0 \%$, compared with $-1.0 \%$ o in oak, Table 1 ) because they have large leaves with less branching thus creating a denser shade than in oak; leaves in deep shade in the lower canopy have even lower $8{ }^{13} \mathrm{C}$ (Broadmeadow et al. 1992; Buchmann et al. 1997).

From the first measurement in Spring 2000, buds had a distinctive sun or shade $8{ }^{13} \mathrm{C}$ signature, which was probably determined by the light environment of the parent branch during the previous year. The observation that the $8{ }^{13} \mathrm{C}$ is distinct from buds that were spatially separated by less than $2 \mathrm{~m}$ clearly supports the carbon autonomy of even quite small branches (Sprugel et al. 1991) and indicates that buds use local carbohydrate stores for leaf expansion, presumably in ray cells in small branches and twigs.

\section{Seasonal pattern in $8^{3} \mathrm{C}$}

Large changes in $8{ }^{13} \mathrm{C}$ of bud and leaf tissues through the season have been reported previously, e.g. Leavitt and Long (1985) and Chevillat et al. (2005). Given the very low photosynthetic rates in the early spring (from DOY 135; Fig. 1), the early changes in $8{ }^{13} \mathrm{C}$ are likely to reflect changing tissue composition through carbohydrate import and transformation. The rapid decline 
in $8{ }^{13} \mathrm{C}$ after bud break may also have been partly caused by the loss of bud scales, which were included in bud samples prior to bud-break. Scales may have had 8BC values closer to stem tissues, which are generally higher than for leaves (mean value of 1.9\%o, Badeck et al. 2005; see also Cemusak et al. 2009). The expanding leaves continued to show large declines in $8{ }^{13} \mathrm{C}$ which are similar to those described for Q. pubescens (Damesin et al. 1998) and Fagus sylvaticus (Damesin and Lelarge 2003; Helle and Schleser 2004). Helle and Schleser (2004) proposed a 3phase explanation; firstly an early-season stage when tissue growth is dominated by starchderived (and consequently ${ }^{13} \mathrm{C}$-enriched) carbon from storage in ray cells or stem phloem. The differences between oak and sycamore in this phase may reflect carbohydrate availability as ring porous oak trees show much larger depletions of non-structural carbohydrate in the stem during bud burst than diffuse porous beech (Barbaroux and Breda 2002). The second phase is a decline in stem and leaf $8 \mathrm{BC}$ during the main growing season, due to the $\mathrm{C}$ pool for growth gradually changing from starch reserves to cmTent photosynthate. This was clearly evident here (Fig. 3); in oak the low spring $A$ rate resulted in a more gradual decline compared to sycamore leaves. An additional contribution to the changing $\mathrm{Be}$ signature may come from refixation of high concentrations of respired ${ }^{13} \mathrm{C}$-enriched $\mathrm{CO}_{2}$ from the stem carried up in the xylem sap (Levy et al. 1999; Helle and Schleser 2004). Keel et al. (2006) inferred from experiments with high $\mathrm{CO}_{2}$ that in Q. petraea leaves only $39 \%$ of the $8{ }^{13} \mathrm{C}$ signal came from the current season's photosynthate. The third phase identified by Helle and Schleser (2004) was a small increase in $8{ }^{13} \mathrm{C}$ late in the growing season as leaves senesce, although this was not evident here. We also note a fourth overwintering phase, during which discrimination in bud processes (such as translocation, storage and remobilisation) result in early season bud values of $8{ }^{13} \mathrm{C}$ which are 3$5 \%$ higher than those of the leaves at the end of the previous season.

The changing balance in Be between newly fixed and 'old' C means that it is difficult to interpret whole tissue $8{ }^{13} \mathrm{C}$ values as resulting from environmental effects on leaf gas exchange unambiguously. In both years there was a slight reduction in $8{ }^{13} \mathrm{C}$ (approximately $-0.5 \% \mathrm{o}$ ) between leaf maturity and the start of senescence (Fig. 3). This is the opposite trend to that expected to occur because of reduced $\mathrm{g}_{5}$ and $\mathrm{C} / \mathrm{Ca}$ caused by with higher light, warmer temperatures, higher f..e and possible increased water stress associated with mid and late summer. Although the gas exchange data were highly variable there is some indication that Algs measured is higher in the earlier summer, at least in sycamore (Fig 2). Thus it is likely that such environmental effects are masked by the changing balance of new and old C. Recent developments in examining $8{ }^{13} \mathrm{C}$ of different components of leaf tissues, particularly rapidly turning-over carbohydrates, are likely to prove more useful than whole tissue analyses (e.g. Damesin and Lelarge 2003; Eglin et al. 2009).

Calculated $A * / g *$ and $\mathrm{Alg}_{5}$

Both 8BC-derived $A^{*} / g^{*}$ and gas exchange derived $\mathrm{Alg}_{5}$ showed that there were no significant differences between sycamore and oak (Table 1). For sun leaves the two approaches agreed to within $10-16 \%$ when the comparison accounted for the boundary layer conductance, gb, which is clearly important, even if leaves are well coupled for much of the time in the upper canopy (Stokes et al. 2006). The higher $A^{*} l g^{*}$ value is surprising, given that respiration losses should reduce the seasonal integrated value. However, the differences probably reflect the inadequate sampling for $A / g_{5}$, uncertainties over the exact value for gb, which will depend upon the wind speed in the canopy, and the large influence of the changing balance between current and stored 
photosynthate. For shade leaves there was no agreement at all, as the mean gas exchange derived Alg values were so low. This is probably due to the difficulty in ensuring a sufficient sample of gas exchange measurements across leaves, weather and light conditions and times of day, and to the different response times of $A$ and $g_{5}$. It is likely that in the open, upper canopy where these measurements took place that 'shade' leaves receive full sunshine at times, particularly at low sun angles. Picon et a!. (1996 and 1997) also found that instantaneous gas exchange measurements of $A / g$ for $Q$. robur and $Q$. petraea were not representative of the daily, integrated values derived from $8{ }^{13} \mathrm{C}$, even when $\mathrm{C}$ isotopic discrimination was measured on soluble carbohydrates rather than whole leaves. The results here reinforce the conclusion of Picon et al. (1997) that spot measurements of leaf gas exchange do not represent the daily integrated values. Furthermore, Seibt et a!. (2008) have recently analysed the different factors that control the instantaneous, intrinsic and integrated WUE values, and highlighted that WUE can vary independently of $8{ }^{13} \mathrm{C}$.

\section{Conclusions}

There was no difference between oak and sycamore leaf WUE in the upper canopy, either determined by $8^{13} \mathrm{C}$ or gas exchange methods. Shade leaves had much lower WUE than the sun leaves, but it was difficult to estimate reliably from gas exchange measurements in the shade. Measurements of the seasonal time-course of leaf $8^{13} \mathrm{C}$ showed that carbohydrate import during bud-break, leaf development and senescence means that it is difficult to interpret whole-tissue $8{ }^{13} \mathrm{C}$ values only in terms of estimated WUE.

\section{Acknowledgements}

VJS held a CASE PhD studentship from NERC during this work. Leaf carbon isotope ratios were analysed at the Stable Isotope Facility, Centre for Ecology and Hydrology, Merlewood Research Station, Cumbria. We thank Oxford University for permission to use the site and canopy walkway, the construction of which was funded by NERC under the TIGER programme to Prof. Chris Perrins. We are grateful to two anonymous reviewers who made helpful comments on an earlier draft. 


\section{References}

Badeck F-W, Tcherkez G, Nogues S, Piel C, Ghasghaie J (2005) Post-photosynthetic fractionation of stable carbon isotopes between plant organs - a widespread phenomenon. Rapid Commun Mass Spectrom 19:1381-1391.

Barbaroux C, Breda N (2002) Contrasting distribution and seasonal dynamics of carbohydrate reserves in stem wood of adult ring-porous sessile oak and diffuse-porous beech trees. Tree Physiol22:1201-1210.

Bassow SL, Bazzaz FA (1998) How environmental conditions affect canopy leaf-level photosynthesis in four deciduous tree species. Ecology 79:2660-2675.

Bovard BD, Curtis PS, Vogel CS, Su H-B, Schmid HP (2005) Environmental controls on sap flow in a northern hardwood forest. Tree Physiol 25:31-38.

Broadmeadow MSJ, Griffiths H, Maxwell C, Borland AM (1992) The carbon isotope ratio of plant organic material reflects temporal and spatial variations in $\mathrm{CO}_{2}$ within tropical forest formations in Trinidad. Oecologia 89:435-441.

Buchmann N, Kao WY, Ehleringer J (1997) Influence of stand structure on carbon-13 of vegetation, soils and canopy air within deciduous and evergreen forests in Utah, United States. Oecologia 110:120-131.

Catovsky S, Holbrook NM, Bazzaz FA (2002) Coupling whole-tree transpiration and canopy photosynthesis in coniferous and broad-leaved tree species. Can. J For Res 32:295-309.

Cernusak LA, Tcherkez G, Keitel C, Cornwell WK, Santiago LS, Knohl A, Barbour MM, Williams DG, Reich PB, Ellsworth DS, Dawson TE, Griffiths HG, Farquhar GD, Wright 11 (2009) Viewpoint: Why are non-photosynthetic tissues generally $C^{13}$-enriched compared with leaves in $\mathrm{C}_{3}$ plants? Review and synthesis of current hypotheses. Functional Plant Biology 36:199-213.

Chevillat VS, Siegwolf RTW, Pepin S, Korner C (2005) Tissue-specific variation of 8C ${ }^{13}$ in mature canopy trees in a temperate forest in central Europe Basic Appl Ecol 6:519-534.

Damesin C, Rambal S, Joffre R (1998) Seasonal and annual change in leaf $8{ }^{13} \mathrm{C}$ in two cooccurring Mediterranean oaks: relations to leaf growth and drought progression. Funct Ecol 12:778-785.

Damesin C, Lelarge C (2003) Carbon isotope composition of current-year shoots from Fagus sylvatica in relation to growth, respiration and use of reserves. Plant Cell Environ 26:207-219. 
Eglin T, Fresneau C, Lelarge-Trouverie C, Francois C, Damesin C (2009) Leaf and twig ${ }^{13}$ C during growth in relation to biochemical composition and respired $\mathrm{CO}_{2}$ Tree Physiol. (in Press) doi:10.1093/treephys/tppO13.

Ellsworth DS, Reich PB (1993) Canopy structure and vertical patterns of photosynthesis and related leaf traits in a deciduous forest. Oecologia 96:169-178.

Evans JR (1989) Photosynthesis and nitrogen relationships in leaves of C3 plants. Oecologia 78:9-19.

Farquhar GD, O'Leary MH, Berry JA (1982) On the relationship between carbon isotope discrimination and the intercellular carbon dioxide concentration in leaves. Aust J Plant Physiol 9:121-137.

Farquhar GD, Ehleringer JR, Hubick KT (1989) Carbon isotope discrimination and photosynthesis, Ann Rev Plant Physiol Plant Mol Biol40:503-537.

Field C (1983) Allocating leaf nitrogen for the maximisation of carbon gain: leaf age as a control on the allocation programme. Oecologia 56:341-347.

Garten CT, Taylor GE Jr (1992) Foliar $8{ }^{13} \mathrm{C}$ within a temperate deciduous forest: Spatial, temporal and species sources ofvariation. Oecologia 90:1-7.

Gutschick VP (1999) Biotic and abiotic consequences of differences in leaf structure. New Phytol 143:3-18.

Helle G, Schleser GH (2004) Beyond $\mathrm{CO}_{2}$-fixation by Rubisco - an interpretation of ${ }^{13} \mathrm{C} /{ }^{12} \mathrm{C}$ variations in tree rings from novel intra-seasonal studies on broad-leaf trees. Plant Cell Environ 27: 367-380.

Hirose T (2005) Development of the Monsi-Saeki theory on canopy structure and function. Ann Bot 95: 483-494

Holscher D (2004) Leaf traits and photosynthetic parameters of sapling and adult trees of coexisting species in a temperate broad-leaved forest. Basic Appl Ecol 5:163-1.72.

Jones HG (2004) What is water use efficiency? In: Water use Efficiency in Plant Biology, pp. 2741. Ed. M A Bacon; Blackwell Publishing, Oxford.

Keel SJ, Siegwolf RTW, Korner C (2006) Canopy $\mathrm{CO}_{2}$ enrichment permits tracing the fate of recently assimilated carbon in a mature deciduous forest. New Phytol 172 (2):319-329.

Kozlowski TT (1992) Carbohydrate sources and sinks in woody plants. Bot Rev 58:107-224.

Kull O, Niinemets U (1993) Variations in leaf morphometry and nitrogen concentration in Betula pendula Roth., Corylus avellana L. and Lonicera xylosteum L. Tree Physiol 12:311-318. 
Le Roux X, Bariac T, Sinoquet H, Genty B, Pie! C, Mariotti A, Girardin C, Richard P (2001) Spatial distribution of leaf water-use efficiency and carbon isotope discrimination within an isolated tree crown. Plant Cell Environ 24:1021-1032

Leavitt SW, Long A (1985) Stable-carbon isotopic composition of maple sap and foliage. Plant Physiol 78:427-429.

Levy PE, Meir P, Allen SJ, Jarvis PG (1999) The effect of aqueous transport of $\mathrm{CO}_{2}$ in xylem sap on gas exchange in woody plants. Tree Physiol 19:53-58

Lowdon JA, Dyck W (1974) Seasonal variations in the isotope ratios of carbon in maple leaves and other plants. Can J Earth Sci 79:79-88.

Matsumoto K, Ohta T, Tanaka T (2005). Dependence of stomatal conductance on leaf chlorophyll concentration and meteorological variables. Agric For Meteorol 132:44-57.

Morecroft MD, Taylor ME, Oliver H (1998) Air and soil microclimates of deciduous woodland compared to an open site. Agric For Meteorol 90:141-156.

Morecroft MD, Roberts J (1999) Photosynthesis and stomatal conductance of mature canopy oak (Quercus robur) and sycamore (Acer pseudoplatanus) trees throughout the growing season. Funct Ecol 13:332-342.

Morecroft MD, Stokes VJ, Morison JIL (2003) Seasonal changes in the photosynthetic capacity of canopy oak (Quercus robur) leaves: the impact of slow development on annual carbon uptake. Int J Biometeorol47:221-226.

Morison JIL, Baker NR, Mullineaux PM, Davies WJ (2008) Improving water use in crop production. Phil Trans Roy Soc SerB 363: 639-658.

Muraoka H, Koizumi H (2005) Photosynthetic and structural characteristics of canopy and shrub trees in a cool-temperate deciduous broadleaved forest: implication to the ecosystem carbon gain. Agric For Meteorol 134:39-59.

Oren R, Pataki DE (2001) Transpiration in response to variation in microclimate and soil moisture in southeastern deciduous forests. Oecologia 127: 549-559.

Osmond CB, Bjorkman O, Anderson DJ (1980) Physiological processes m plant ecology. Springer, New York.

Pearcy RW, Krall JP, Sassenrath-Cole GF (1996) Photosynthesis in fluctuating light environments, In: Photosynthesis and the Environment. Baker NR (ed) Kluwer Academic Publishers, The Netherlands. p321-346. 
Pearcy RW (1998) Acclimation to sun and shade. In: Photosynthesis: a comprehensive treatise. Raghavendra AS (ed) Cambridge University Press, Cambridge, UK.

Picon C, Guehl J-M, Ferhi A (1996) Leaf gas exchange and carbon isotope composition responses to drought in a drought-avoiding (Pinus pinaster) and a drought-tolerant (Quercus petraea) species under present and elevated atmospheric C02 concentrations. Plant Cell Environ 19:182-190.

Picon C, Ferhi A, Guehl J-M (1997) Concentration and $8{ }^{13} \mathrm{C}$ of leaf carbohydrates in relation to gas exchange in Quercus robur under elevated C02 and drought, J Exp Bot 48:1547-1556.

Ponton S, Dupouey J-L, Breda N, Feuillat F, Bodenes C, Dreyer E (2001) Carbon isotope discrimination and wood anatomy variations in mixed stands of Quercus robur and Quercus petraea. Plant Cell Environ 24:861-868.

Rao RG, Woitchick AF, Goeyens L, van Riet A, Kazungu J, Dehairs F (1994) Carbon, nitrogen contents and stable carbon isotope abundance in mangrove leaves from an East African coastal lagoon (Kenya). Aquat Bot 47:175-183.

Rodwell JS (1991) British Plant Communities. Vol. 1. Woodlands and Scrub. Cambridge University Press, Cambridge, UK.

Schulze E-D, Kelliher FM, Korner C, Lloyd J, Leuning R (1994) Relationships among maximum stomatal conductance, ecosystem surface conductance, carbon assimilation rate, and plant nitrogen nutrition: a global ecology scaling exercise. Annu Rev Ecol Syst 25:629-660.

Seibt U, Rajabi A, Griffiths H, Berry JA (2008) Carbon isotopes and water use efficiency: sense and sensitivity. Oecologia 155:441-454.

Sprugel DG, Hinckley TM, Schaap W (1991) The theory and practice of branch autonomy. Ann Rev Ecol Systematics 22:309-334.

Stokes VJ, Morecroft MD, Morison JIL (2006) Boundary layer conductance for contrasting leaf shapes in a deciduous broadleaved forest canopy, Agric For Meteorol 139:40-54.

Sullivan NH, Bolstad PV, Vose JM (1996) Estimates of net photosynthetic parameters for twelve species in mature forests of the southern Appalachian. Tree Physiol 16:397-406.

Terwilliger VJ (1997) Changes in the $8{ }^{13} \mathrm{C}$ values of trees during a tropical rainy season: some effects in addition to diffusion and carboxylation by Rubisco. Am J Bot 84:1693-1700.

Urban O, Kosvancova N, Marek MV, Lichtenthaler HK (2007) Induction of photosynthesis and importance of limitations during the induction phase in sun and shade leaves of five ecologically contrasting tree species from the temperate zone. Tree Physiol27: 1207-1215. 
Victoria J. Stokes

Wilson KB, Baldocchi DD, Hanson PJ (2000) Spatial and seasonal variability of photosynthetic parameters and their relationship to leaf nitrogen in a deciduous forest. Tree Physiol 20: 565-578.

Wong SC, Cowan IR, Farquhar GD (1979) Stomatal conductance correlates with photosynthetic capacity. Nature 282: 424-426. 
Tables

Table 1. Mean seasonal values of net $\mathrm{CO} 2$ assimilation rate $(\mathrm{A})$, intrinsic water use efficiency $\left(\mathrm{A} / \mathrm{g}_{5}\right),{ }^{13} \mathrm{C}$ discrimination $\left(8{ }^{13} \mathrm{C}\right)$ and long term water use efficiency $\left(\mathrm{A}^{*} / \mathrm{g}^{*}\right)$ for oak and sycamore canopy leaves in sun or shade positions. Also shown are photosynthetic photon flux densities (PPFD) and leaf temperatures during measurements, and values of $\mathrm{A} / \mathrm{g}$ calculated using a boundary layer conductance estimate (see text for details). Calculated from all mean daily values between day of year 125 and 320 (i.e. excluding bud $8^{13} \mathrm{C}$ measurements). Figures in brackets are s.e.m.

\begin{tabular}{|c|c|c|c|c|c|c|c|c|}
\hline \multirow{3}{*}{ parameter } & \multicolumn{4}{|c|}{1999} & \multicolumn{4}{|c|}{2000} \\
\hline & \multicolumn{2}{|c|}{ oak } & \multicolumn{2}{|c|}{ sycamore } & \multicolumn{2}{|c|}{ oak } & \multicolumn{2}{|c|}{ sycamore } \\
\hline & sun & shade & sun & shade & sun & shade & sun & shade \\
\hline $\begin{array}{l}8^{13} \mathrm{C} \\
\% 0\end{array}$ & $\begin{array}{l}-27.9 \\
(0.1)\end{array}$ & $\begin{array}{l}-28.9 \\
(0.1)\end{array}$ & $\begin{array}{l}-27.7 \\
(0.1)\end{array}$ & $\begin{array}{l}-29.2 \\
(0.1)\end{array}$ & $\begin{array}{l}-27.6 \\
(0.2)\end{array}$ & $\begin{array}{l}-28.6 \\
(0.2)\end{array}$ & $\begin{array}{l}-27.3 \\
(0.1)\end{array}$ & $\begin{array}{l}-29.3 \\
(0.2)\end{array}$ \\
\hline $\begin{array}{l}A \\
11 \mathrm{~mol} \mathrm{~m}^{-} \mathrm{s}^{-1}\end{array}$ & $\begin{array}{l}7.71 \\
(0.60)\end{array}$ & $\begin{array}{l}0.47 \\
(0.14)\end{array}$ & $\begin{array}{l}4.89 \\
(0.56)\end{array}$ & $\begin{array}{l}0.48 \\
(0.17)\end{array}$ & $\begin{array}{l}8.32 \\
(0.65)\end{array}$ & $\begin{array}{l}0.72 \\
(0.23)\end{array}$ & $\begin{array}{l}5.75 \\
(0.62)\end{array}$ & $\begin{array}{l}1.17 \\
(0.32)\end{array}$ \\
\hline $\begin{array}{l}A / g_{5} \\
11 \mathrm{~mol} \mathrm{C02} \mathrm{[mol} \mathrm{H2Or}{ }^{1}\end{array}$ & $\begin{array}{l}49.7 \\
(2.6)\end{array}$ & $\begin{array}{l}4.95 \\
(1.41)\end{array}$ & $\begin{array}{l}50.1 \\
(4.5)\end{array}$ & $\begin{array}{l}6.28 \\
(2.14)\end{array}$ & $\begin{array}{l}46.9 \\
(3.1)\end{array}$ & $\begin{array}{l}9.95 \\
(1.65)\end{array}$ & $\begin{array}{l}50.1 \\
(5.0)\end{array}$ & $\begin{array}{l}8.40 \\
(2.27)\end{array}$ \\
\hline $\begin{array}{l}A / g \\
\text { Jlmol C02 [mol H20r }\end{array}$ & $\begin{array}{l}64.5 \\
(3.5)\end{array}$ & $\begin{array}{l}6.14 \\
(1.65)\end{array}$ & $\begin{array}{l}64.9 \\
(5.9)\end{array}$ & $\begin{array}{l}8.02 \\
(2.57)\end{array}$ & $\begin{array}{l}62.9 \\
(3.8)\end{array}$ & $\begin{array}{l}11.8 \\
(2.0)\end{array}$ & $\begin{array}{l}67.1 \\
(6.4)\end{array}$ & $\begin{array}{l}10.8 \\
(2.7)\end{array}$ \\
\hline $\begin{array}{l}A^{*} \lg ^{*} \\
11 \mathrm{~mol} \text { C02 [molli20r }{ }^{1}\end{array}$ & $\begin{array}{l}71.8 \\
(1.2)\end{array}$ & $\begin{array}{l}61.2 \\
(1.3)\end{array}$ & $\begin{array}{l}73.3 \\
(1.3)\end{array}$ & $\begin{array}{l}58.7 \\
(1.3)\end{array}$ & $\begin{array}{l}74.9 \\
(2.3)\end{array}$ & $\begin{array}{l}64.6 \\
(2.4)\end{array}$ & $\begin{array}{l}77.5 \\
(1.4)\end{array}$ & $\begin{array}{l}57.5 \\
(2.0)\end{array}$ \\
\hline $\begin{array}{l}\text { PPFD } \\
\text { Jlmol m- }{ }^{2} \mathrm{~s}^{1}\end{array}$ & $\begin{array}{l}1108 \\
(91)\end{array}$ & $\begin{array}{l}139 \\
(23)\end{array}$ & $\begin{array}{l}1114 \\
(120)\end{array}$ & $\begin{array}{l}70.5 \\
(10.0)\end{array}$ & $\begin{array}{l}697 \\
(59)\end{array}$ & $\begin{array}{l}130 \\
(6)\end{array}$ & $\begin{array}{l}640 \\
(65)\end{array}$ & $\begin{array}{l}141 \\
(10)\end{array}$ \\
\hline $\begin{array}{l}\text { Leaf temperature } \\
\text { oc }\end{array}$ & $\begin{array}{l}22.2 \\
(0.7)\end{array}$ & $\begin{array}{l}21.6 \\
(1.0)\end{array}$ & $\begin{array}{l}23.0 \\
(1.1)\end{array}$ & $\begin{array}{l}21.6 \\
(0.9)\end{array}$ & $\begin{array}{l}17.7 \\
(0.5)\end{array}$ & $\begin{array}{l}17.4 \\
(0.5)\end{array}$ & $\begin{array}{l}17.6 \\
(0.5)\end{array}$ & $\begin{array}{l}17.3 \\
(0.5)\end{array}$ \\
\hline
\end{tabular}




\section{Figures and Legends}

\section{Fig. 1}

Seasonal time course of net $\mathrm{CO}_{2}$ assimilation rate $(A)$ for oak and sycamore sun (open symbols) and shade (solid symbols) leaves in the canopy, measured in ambient light. Data for 1999 are shown as o - (oak) and 11 .4. (sycamore). The data for 2000 are shown as $\mathbf{O}^{\bullet}$ (oak) and $\mathrm{V}^{\prime} \mathbf{T}$ (sycamore) and are advanced by 12 days, due to later bud break and leaf fall. Values are daily means of measurements taken on 5 leaves from each of 1-5 trees with S.E. bars.

\section{Fig. 2}

Seasonal time course of intrinsic water use efficiency (Aigs) for oak and sycamore sun (open symbols) and shade (solid symbols) leaves in the canopy, measured in ambient light during 1999 and 2000. Other details as in Figure 1.

\section{Fig. 3}

Leaf $8{ }^{13} \mathrm{C}(\%)$ values for (a) 1999 and (b) 2000 in oak (circles) and sycamore (triangles) in sun (open symbols) and shade leaves (solid symbols). Values are single measurements pooled from 5 leaf samples in 1999 and means of samples from 5 different trees with S.E. bars. $\mathrm{BB}=$ budbreak, $\mathrm{LFE}=$ leaf full expansion, $\mathrm{LM}=$ leaf maturation, $\mathrm{SS}=$ start of senescence.

\section{Fig. 4}

Change in $8{ }^{13} \mathrm{C}(\%)$ of sun (a) and shade (b) buds and leaves over 2 growing seasons. Oak shown as open bars and sycamore as grey bars. Bars are in sequence: leaves mid season and end of season in 1999, buds at bud break in 2000, leaves mid and end of season in 2000. Data redrawn from Figure 3 with S.E. bars.

\section{Fig. 5}

Relationship between $8{ }^{13} \mathrm{C}(\% 0)$ and \% water content of bud and leaf samples of (a) oak sun (open symbols) and shade (solid symbols) and (b) sycamore sun and shade in 2000. Points joined as a time series starting at *. Horizontal s.e. bars omitted for clarity. Dashed lines are fitted by eye to all points excluding the first four leading up to and including bud break. 
Fig I

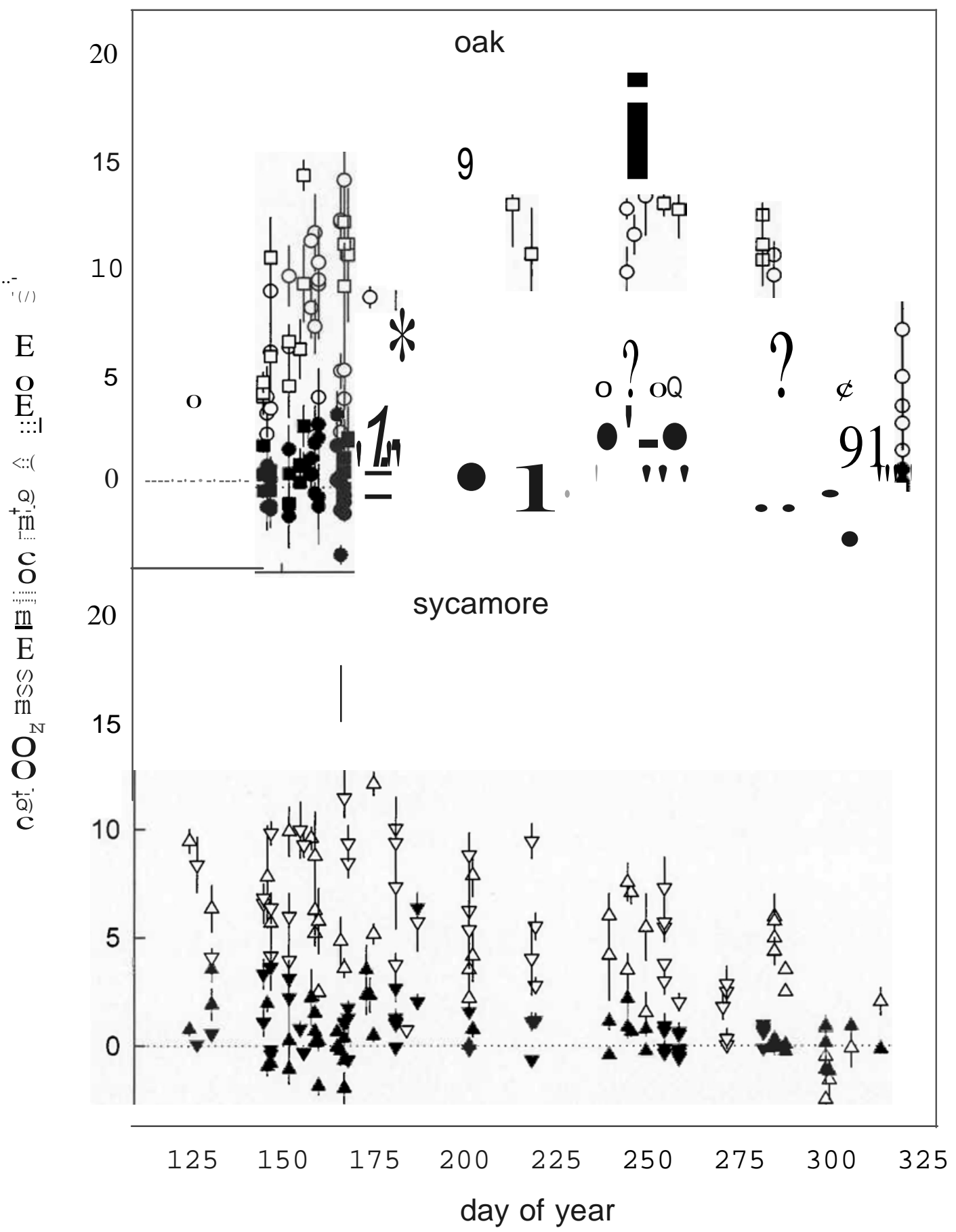


Fig2.

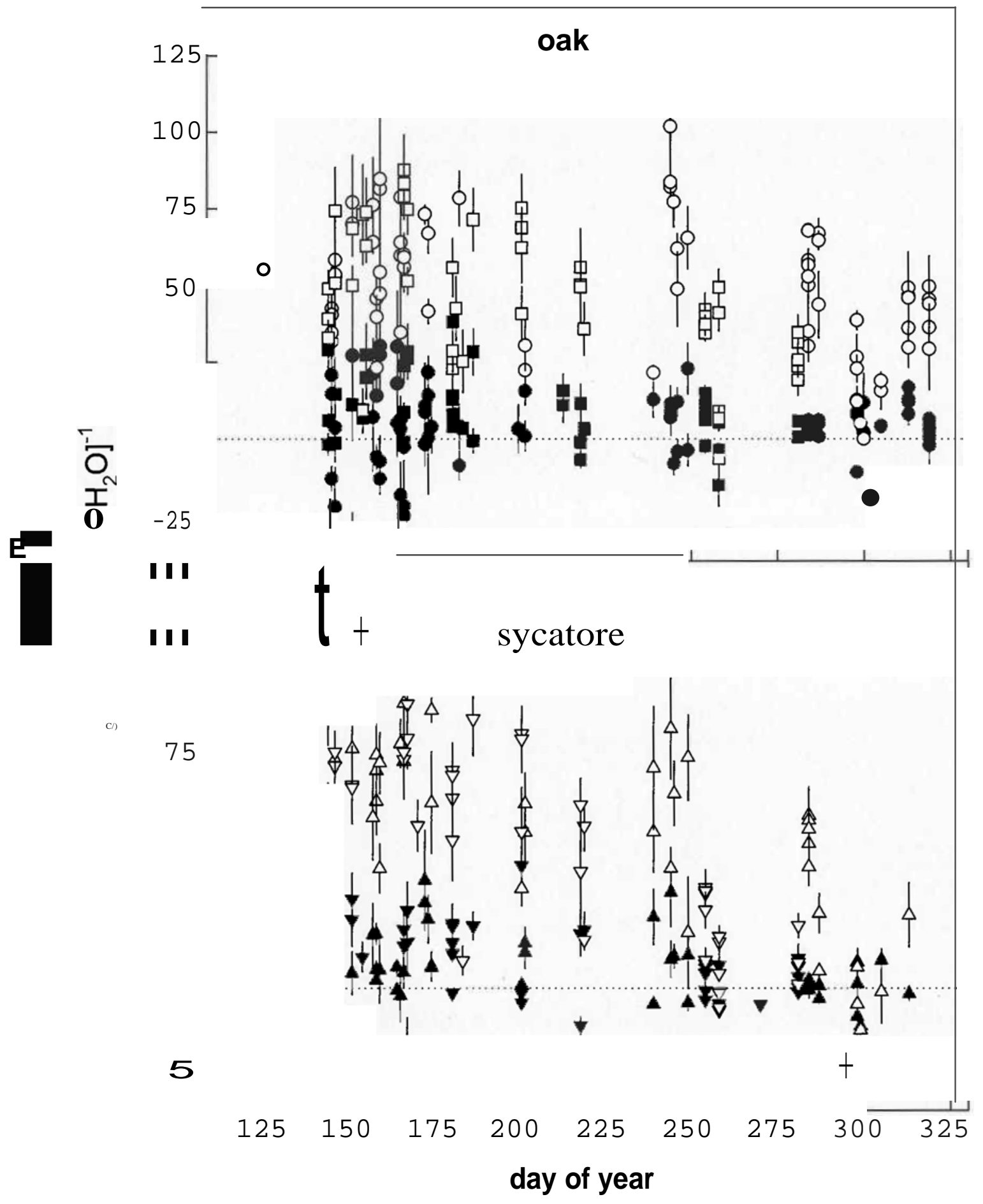


Fig 3

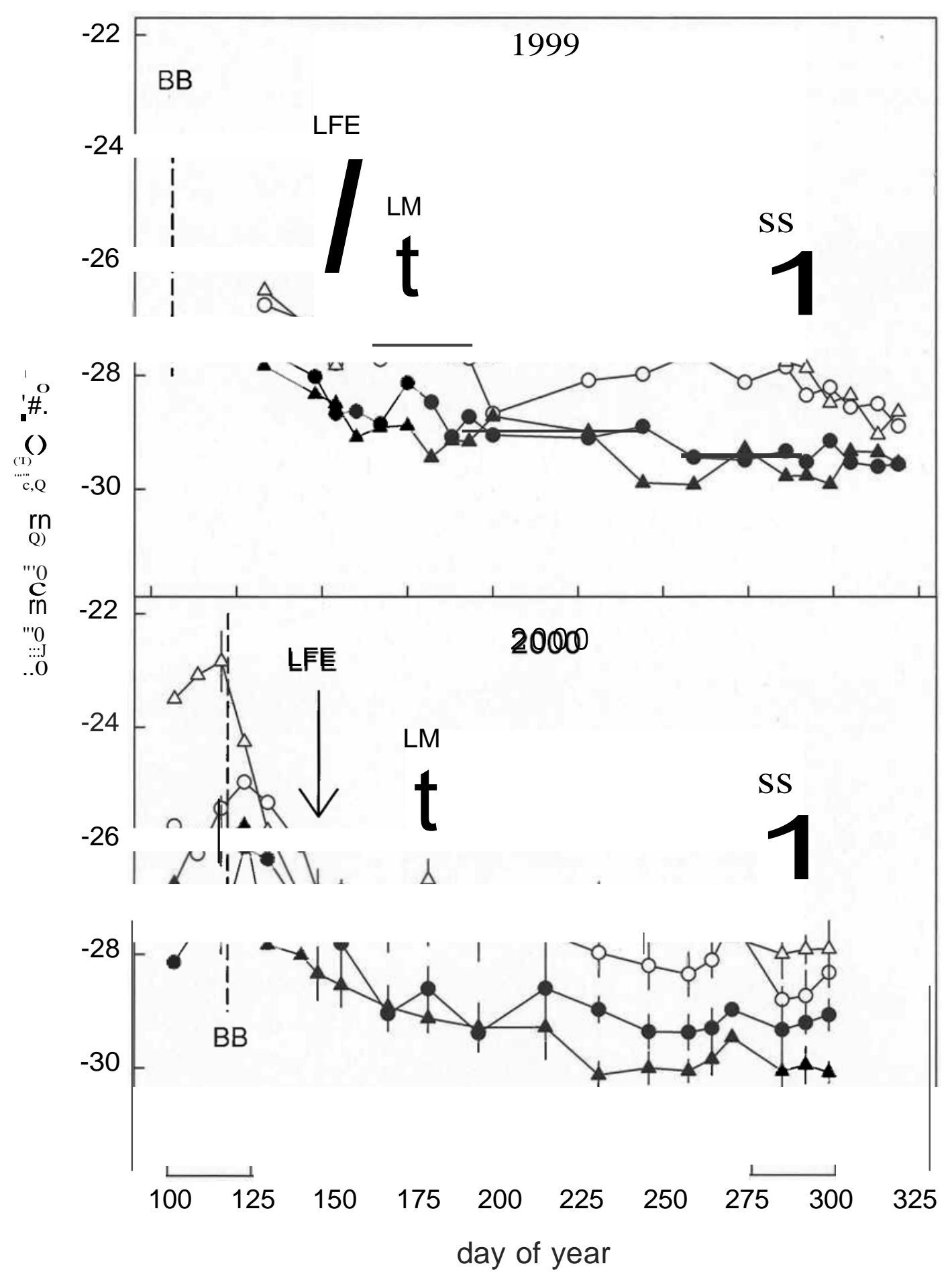


Fig. 4

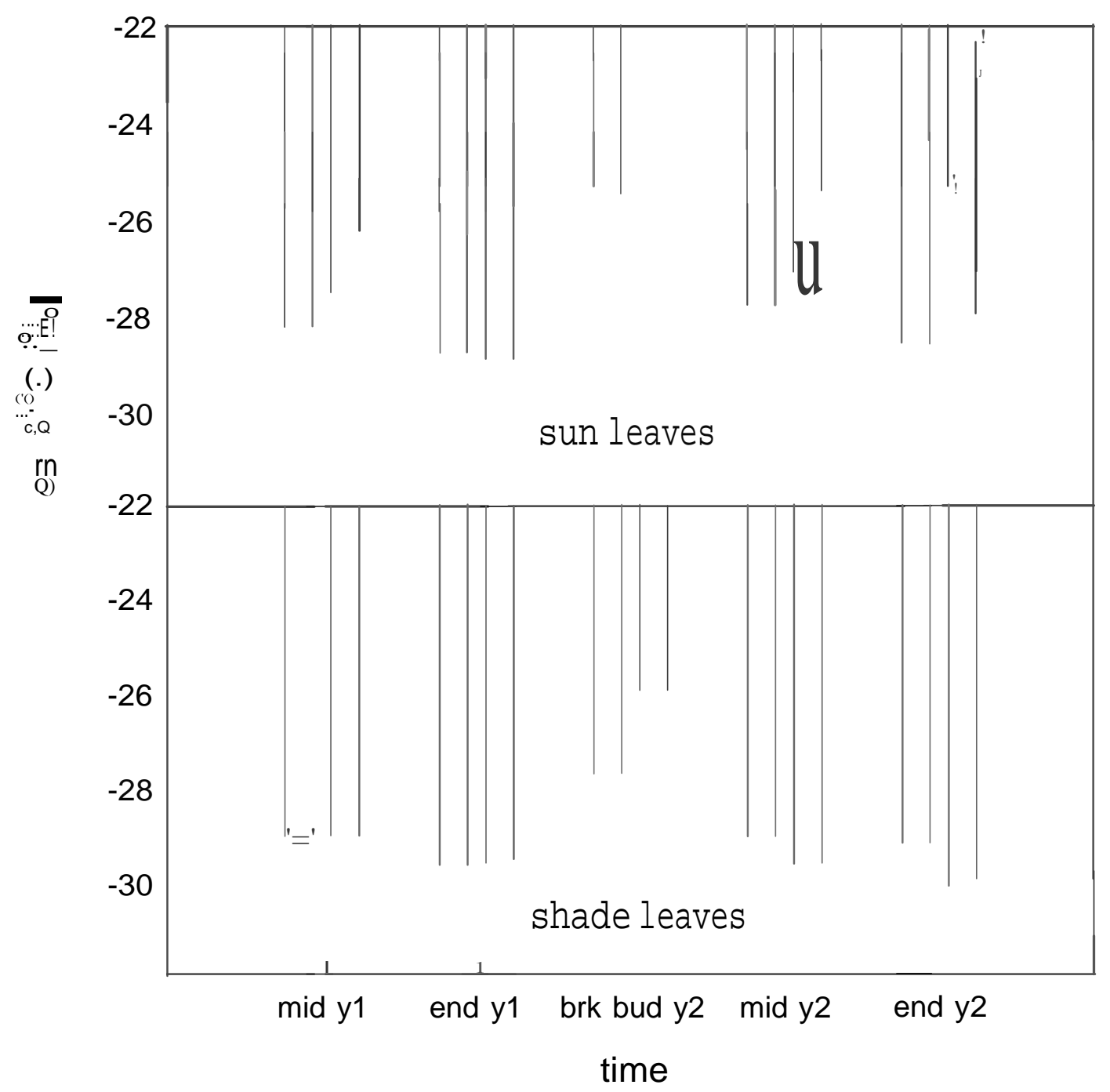


Fig 5

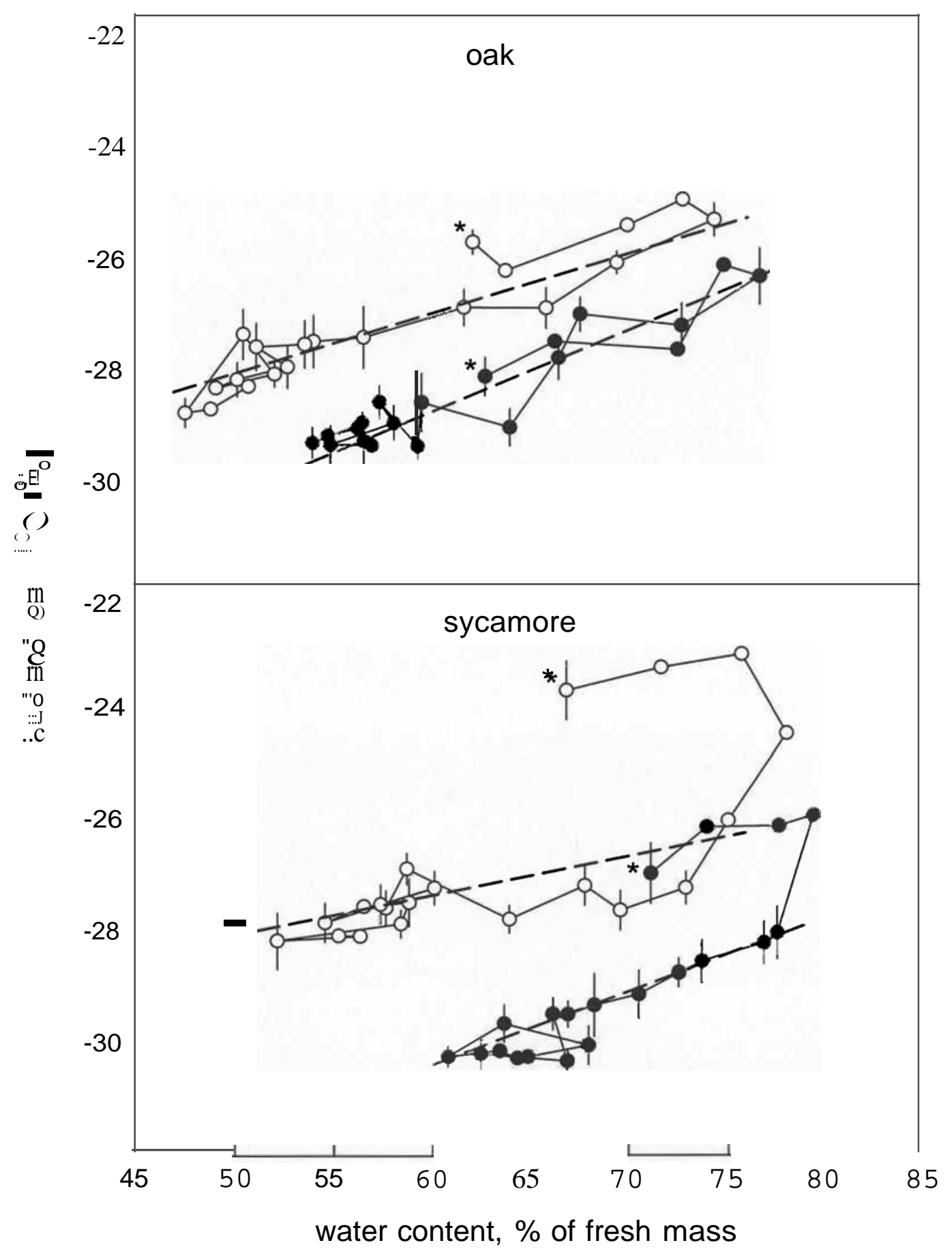

